\title{
2D map of proteins from human renal stone matrix and evaluation of their effect on oxalate induced renal tubular epithelial cell injury
}

\author{
K.P. Aggarwal, S. Tandon, S.K. Singh, C. Tandon \\ Department of Biotechnology and Bioinformatics, Jaypee University of Information Technology (KPA, CT, \\ ST), Waknaghat, Solan, HP and Department of Urology, Post Graduate Institute of Medical Education \& \\ Research (PGIMER) (SKS), Chandigarh-160012 India
}

\section{ABSTRACT}

Purpose: Proteins constitute a major portion of the organic matrix of human calcium oxalate $(\mathrm{CaOx})$ renal stones and the matrix is considered to be important in stone formation and growth. The present study evaluates the effect of these proteins on oxalate injured renal epithelial cells accompanied by a 2D map of these proteins.

Materials and Methods: Proteins were isolated from the matrix of kidney stones containing $\mathrm{CaOx}$ as the major constituent using EGTA as a demineralizing agent. The effect of more than $3 \mathrm{kDa}$ proteins from matrix of human renal (calcium oxalate) $\mathrm{CaOx}$ stones was investigated on oxalate induced cell injury of MDCK renal tubular epithelial cells. A $2 \mathrm{D}$ map of $>3 \mathrm{kDa}$ proteins was also generated followed by protein identification using MALDI-TOF MS.

Results: The $>3 \mathrm{kDa}$ proteins enhanced the injury caused by oxalate on MDCK cells. Also, the $2 \mathrm{D}$ map of proteins having MW more than $3 \mathrm{kDa}$ suggested the abundance of proteins in the matrix of renal stone.

Conclusion: Studies indicate that the mixture of $>3 \mathrm{kDa}$ proteins in the matrix of human renal stones acts as promoter of calcium oxalate crystal nucleation and growth as it augments the renal epithelial cell injury induced by oxalate. The effect of promoters masks the inhibitors in the protein mixture thereby leading to enhanced renal cell injury. 2D map throws light on the nature of proteins present in the kidney stones.

\section{ARTICLE INFO}

\author{
Key words: \\ Urolithiasis; Calcium Oxalate; \\ Madin Darby Canine Kidney \\ Cells; Electrophoresis, Gel, \\ Two-Dimensional
}

Int Braz J Urol. 2013; 39: 128-36

Submitted for publication:

August 14, 2012

Accepted after revision:

November 30, 2012

\section{INTRODUCTION}

With its multifactor aetiology and high rate of recurrences, urinary tract stone disease provides a medical challenge. Depending on the socio-economic conditions and subsequent changes in the dietary habits, the overall probability of stone formers differs in various parts of the world: 1-5\% Asia, 5-9\% Europe, 13-15\% USA and 20\% Saudi Arabia (1). Calcium containing stones are the most common, consisting of about $75 \%$ of all urinary calculi, which may be in the form of pure calcium oxalate $(50 \%)$ or calcium phosphate $(5 \%)$ and a mixture of both (45\%). The controlling influence of macromolecules in the construction of healthy biomineralised tissues is undisputed (2-4). It is now well recognised that the organic component of such tissues, which in animals include bone, shell, dentin and enamel, is crucial to the biomineralization process. Some macromolecules 
in these systems are responsible for initiating mineralisation, defining its physical limits and dictating its cessation, but others provide an architectural framework upon which the inorganic salts are laid down. Less clearly defined, however, are the roles played by macromolecules in the formation of human uroliths, a process possessing all the hallmarks of uncontrolled mineralisation $(5,6)$.

Many proteins occur in stone, but their role in urolithiasis remains unknown. Calculi contains some proteins normally present in urine, in addition to others arising from injury inflicted by the stones themselves, making it impossible to discriminate between those that bind to the stone as it grows, but play no role in its development (7); the inhibition is generally understood to arise mainly from the non-dialyzable molecules of urine, particularly acid glycoproteins, and acidic glycoproteins and glycosaminoglycans $(8,9)$. Some inhibitor molecules have been identified, including Tamm-Horsefall Protein, uropontin $(10,11)$, calgranulin (12), bikunin (13), and prothrombin F1 fragment (14). Thus, in order to understand the mechanism of stone genesis, it is essential to determine the characteristics of molecules constituting the urinary stone matrix. In the present study, we analysed a 2D map (2- dimensional polyacrylamide gel electrophoresis) of human renal stone matrix proteins by MALDI-TOF (Matrix-assisted laser desorption/ionization-Time of Flight) to throw light on the matrix proteins and also study their effect on oxalate injured renal epithelial cells.

\section{MATERIALS AND METHODS}

\section{Human Renal stones collection}

Stones surgically removed by Percutaneous nephrolithotomy (PNL) from the kidney stone patients were obtained from the Department of Urology, Postgraduate Institute of Medical Education and Research (PGIMER), Chandigarh, India. Stones were preserved at $4^{\circ} \mathrm{C}$ before study. Stones were of non-infectious nature and were collected from those patients who were more than 25 years of age and were suffering from no other abnormality. After FTIR (Fourier transform infrared spectroscopy) analysis, the stones with calcium and oxalate as their major components were selected for present study. Thirty stones with calcium and oxalate, as the major components were used for further studies. Thirty stone samples were randomly pooled into 5 groups, each group containing 6 stone samples.

\section{Protein extraction from Human Renal stones}

Proteins were isolated from the matrix of kidney stones containing calcium oxalate $(\mathrm{CaOx})$ as the major constituent using EGTA as a demineralising agent. Stones were washed in $0.15 \mathrm{M}$ sodium chloride $(\mathrm{NaCl})$ and were then dried and pulverized with a mortar and pestle. For extraction of the organic matrix of powdered stone, each gram of stone was suspended in $10 \mathrm{~mL}$ of $0.05 \mathrm{M}$ EGTA (ethylene glycol tetraacetic acid), $1 \mathrm{mM}$ PMSF (phenylmethanesulfonylfluoride or phenylmethylsulfonyl fluoride) and 1\% $\beta$-mercaptoethanol. The extraction was carried out for 4 days at $4^{\circ} \mathrm{C}$ with constant stirring. The suspension was centrifuged for 30 minutes at $10,000 \mathrm{~g}$ and at $4^{\circ} \mathrm{C}$. The supernatant of EGTA extract was filtered through Amicon ultra centrifugal filter device (Catalog UFC 800324 ) with a molecular weight cut off $3 \mathrm{kDa}$ at $4^{\circ} \mathrm{C}$ and concentrated to a known volume. The excess of the $3 \mathrm{kDa}$ fractions were stored at $-20^{\circ} \mathrm{C}$ for further studies (15).

\section{Protein determination}

Total protein concentration was determined by Lowry's method using BSA as a standard (16).

Assay to measure inhibitory activity of protein w.r.t Calcium Oxalate (CaOx) crystal nucleation

The method used was similar to that described by Hennequin et al. with some minor modifications (17). Solutions of calcium chloride $\left(\mathrm{CaCl}_{2}\right)$ and sodium oxalate $\left(\mathrm{Na}_{2} \mathrm{C}_{2} \mathrm{O}_{4}\right)$ were prepared at the final concentration of $3 \mathrm{mmoL} / \mathrm{L}$ and 0.5 $\mathrm{mmoL} / \mathrm{L}$, respectively, in a buffer containing Tris $0.05 \mathrm{moL} / \mathrm{L}$ and $\mathrm{NaCl} 0.15 \mathrm{moL} / \mathrm{L}$ at $\mathrm{pH}$ 6.5. Both solutions were filtered through a $0.22 \mu \mathrm{m}$ filter; $1.5 \mathrm{~mL}$ of $\mathrm{CaCl}_{2}$ solution was mixed with different concentrations of extracted proteins. Crystallization was started by adding $1.5 \mathrm{~mL}$ of $\mathrm{Na}_{2} \mathrm{C}_{2} \mathrm{O}_{4}$ solution. The final solution was stirred at $37^{\circ} \mathrm{C}$ repeatedly after an interval of $60 \mathrm{sec}$ for $8 \mathrm{~min}$. The 
absorbance of the solution was monitored at 620 $\mathrm{nm}$ after every $60 \mathrm{sec}$. The percentage inhibition produced by the protein extract was calculated as [1-(Tsi/Tsc)] X 100, where Tsc was the turbidity slope of the control and Tsi the turbidity slope in the presence of the inhibitor.

Assay to measure activity of protein w.r.t. $\mathrm{CaOx}$ crystal growth

Activity against $\mathrm{CaOx}$ crystal growth was measured using the seeded, solution-depletion assay, according to the method described by Nakagawa et al. (18).

\section{Cell Culture}

Madin-Darby Canine kidney (MDCK) cells were obtained from National Centre of Cell Sciences (NCCS, Pune). The cells were maintained as monolayers in Dulbecco's Modified Eagle's Medium (DMEM) with $2.0 \mathrm{mM}$ L-glutamine adjusted to contain $3.7 \mathrm{~g} / \mathrm{L}$ sodium bicarbonate, $4.5 \mathrm{~g} / \mathrm{L}$ glucose. Media was supplemented with 1\% Penicillin (100 units/mL)-Streptomycin $(10,000 \mu \mathrm{g} / \mathrm{mL})$ and 10\% fetal bovine serum. Cells were cultured in $25 \mathrm{~cm}^{2}$ tissue-culture treated flasks at $37^{\circ} \mathrm{C}$ and $5 \% \mathrm{CO}_{2}$ in humidified chambers (19).

\section{Oxalate-induced Cell Injury}

MDCK cells were incubated in DMEM containing $1 \mathrm{mM}$ sodium oxalate in the presence of different concentrations of protein samples for 48 hours (20). Cell injury was assessed by measuring the cell viability through MTT and LDH (Lactate dehydrogenase) Assay.

\section{Preparation of the protein samples}

For cell culture studies, the proteins was dialysed through Millipore Amicon Ultra Centrifugal Filters, 3kDa and desalted by ReadyPrep 2-D Cleanup Kit (catalog 163-2130) and it was reconstituted in $0.22 \mu \mathrm{m}$ filtered distilled water using Millipore Millex GV Filter Unit $0.22 \mu \mathrm{m}$ (Catalog SLGU033RS).

\section{MTT Assay}

Cell viability studies via MTT test were conducted by the method described by Fulya Karamustafa et al. with slight modifications (21).
MDCK cells were suspended in DMEM with serum and plated into the microwells of 96-well tissue culture plates. Plates were incubated for $24 \mathrm{~h}$ at $37^{\circ} \mathrm{C}$ in a humidified incubator containing 5\% $\mathrm{CO}_{2}$. Then the medium was removed from wells. $200 \mu \mathrm{L}$ DMEM (without serum) containing different concentrations of proteins with and without sodium oxalate were added into the wells. After 48 hours, the medium was removed. Each well was treated with $100 \mu \mathrm{L}$ medium and $13 \mu \mathrm{L}$ MTT solution, and incubated for a further 3 hours. Then, plates were emptied and $100 \mu \mathrm{L}$ isopropanol was added to dissolve the formazan precipitate. The developed colour was read at a wavelength of 570 $\mathrm{nm}$ with spectrophotometer.

\section{LDH Leakage Assay}

MDCK cells were suspended in DMEM with serum and plated into the microwells of 96-well tissue culture plates. Plates were incubated for 24 $\mathrm{h}$ at $37^{\circ} \mathrm{C}$ in a humidified incubator containing 5\% $\mathrm{CO} 2$. Then the medium was removed from wells. $200 \mu \mathrm{L}$ DMEM (without serum) containing different concentrations of proteins with and without sodium oxalate were added into the wells for 48 hours. LDH leakage assay was performed by the LDH Cytotoxicity Assay Kit (Cayman 10008882) according to the manufacturer's instructions (22).

\section{Statistical analysis}

Data were expressed as mean values of three independent experiments (each in triplicate) and analyzed by the analysis of variance ( $p<$ $0.05)$ to estimate the differences between values.

\section{2-D Gel Electrophoresis}

The samples were desalted using ReadyPrep 2-D Cleanup Kit and dissolved in $125 \mu \mathrm{L}$ of sample rehydration buffer containing $8 \mathrm{M}$ urea, $2 \% \mathrm{w} / \mathrm{v}$ CHAPS, $50 \mathrm{mM}$ DTT, $0.2 \% \mathrm{w} / \mathrm{v}$ Ampholytes and $0.0002 \%$ bromophenol blue. IEF was first carried out using Bio-Rad IPG strip (pH 3-9; $7 \mathrm{~cm}$ ) in Bio-Rad protean IEF cell according to manufacturer's instructions, followed by equilibration for 15 minutes each in equilibration buffer I (6 M Urea, 2\% SDS, $0.375 \mathrm{M}$ Tris $\mathrm{HCl}(\mathrm{pH}$ 8.8), 20\% Glycerol, 130mM DTT) and equilibra- 
tion buffer II (6 M Urea, 2\% SDS, $0.375 \mathrm{M}$ Tris $\mathrm{HCl}$ (pH 8.8), 20\% Glycerol, 135mM Iodoacetamide). Equilibrated IPG strips were loaded onto a $10 \%$ polyacrylamide gel sealed with overlay agarose, and electrophoresed at a constant voltage of $100 \mathrm{~V}$. The gel was stained by silver staining and analysed using Biorad PD Quest Advanced 2D Analysis Software. The spots of interest were manually excised from the gel and were destained using destainer provided in the ProteoSilver ${ }^{\mathrm{TM}}$ Plus Silver Stain Kit (PROTSIL2, Sigma-Aldrich Co.) followed by in-gel digestion using Trypsin profile IGD kit (PP0100, Sigma-Aldrich Co.). The proteins were identified by matrix assisted laser desorption/ionization-time of flight (MALDI-TOF) MS followed by MASCOT database search.

\section{Tryptic in-gel digestion of purified protein}

Single band detected after molecular-sieve chromatography was excised from the gel and was destained with destainer provided in the ProteoSilver $^{\mathrm{rM}}$ Plus Silver Stain Kit (PROTSIL2, Sigma-Aldrich Co.). Trypsin profile IGD kit (PPO100, Sigma-Aldrich Co.) was used for in-gel digestion of purified protein. Destained gel piece was dried for approximately 15 to $30 \mathrm{~min}$. Trypsin solubilised in $1 \mathrm{mmoL} / \mathrm{L} \mathrm{HCl}$ and mixed with $40 \mathrm{mmoL} / \mathrm{L}$ ammonium bicarbonate and 9\% acetonitrile was added to the destained gel piece. Gel piece was fully covered by the addition of $40 \mathrm{mmoL} / \mathrm{L}$ ammonium bicarbonate and 9\% acetonitrile ( $\mathrm{pH} 8.2$ ) solution and was incubated for 5 hours at $37^{\circ} \mathrm{C}$. After the incubation, liquid was removed from the gel piece and transferred to a new labeled Eppendorf tubes and was preserved for mass spectroscopic analysis (23).

\section{Peptide mass fingerprinting by MALDI-TOF-MS}

Peptides were extracted into the extraction solution and dried by speedvac. Dried spots samples were spotted onto the MALDI plate with thorough mixing with matrix at 1:1 concentration and analyzed by MALDI TOF/TOF ULTRALFLEX III (Bruker Daltonics).

\section{Mascot Protein Identification}

The mass/charge spectra obtained were searched in MASCOT search engine (http://www.matrixscience.com) using all the 3 databases (MSDB,
SwissProt, NCBInr). For search, peptides were assumed monoisotopic, oxidized at methionine residues and carbamidomethylated at cysteine residues. An Homo sapiens taxonomy restriction was used, only one missed cleavage was allowed, and peptide mass tolerance of $1.2 \mathrm{kDa}$ was used for peptide mass fingerprinting.

\section{RESULTS}

Activity study of proteins from human renal stone on $\mathrm{CaOx}$ assay system

Whole EGTA extract and $>3 \mathrm{kDa}$ were assayed to measure the activity against $\mathrm{CaOx}$ crystal nucleation and growth. Different concentrations of whole extract showed both promoter and inhibitory activity against nucleation of $\mathrm{CaOx}$ crystal as well as $\mathrm{CaOx}$ growth.

\section{Bioactivity of $>3 \mathrm{kDa}$ fraction on Oxalate Injured MDCK cells}

Activity of $>3 \mathrm{kDa}$ fraction was analyzed to measure the effect of these proteins on oxalate injured MDCK cells. MTT (Figure-1) and LDH (Figure-2) assays were used for analyzing the effect of the proteins on oxalate injured MDCK renal epithelial cells. The oxalate induced a significant injury to the cells which could be ascertained by a decrease in viability in MDCK cells. The protein extract alone $(40 \mu \mathrm{g} / \mathrm{mL})$ had no effect on the cell injury in the absence of oxalate indicating that even at the highest concentration of protein extract used there was no cytotoxicity to the cells. $>3 \mathrm{kDa}$ fraction showed to both prevent and enhance the injury caused by oxalate on MDCK cells in a dose dependent manner. Concentrations of $5 \mu \mathrm{g} / \mathrm{mL}, 10 \mu \mathrm{g} / \mathrm{mL}, 20$ $\mu \mathrm{g} / \mathrm{mL}$ and $40 \mu \mathrm{g} / \mathrm{mL}$ were used. Concentration of 5 $\mu \mathrm{g} / \mathrm{mL}$ showed protective effect, thereby increasing the cell viability to the oxalate injured cells. But as the concentration increased from $5 \mu \mathrm{g} / \mathrm{mL}$ to $40 \mu \mathrm{g} /$ $\mathrm{mL}$ the cell viability decreased in a dose dependent manner reflecting the enhanced injury caused by the proteins present. The concentration dependent percentage viability was observed in both the assays i.e. MTT and LDH. Both MTT and LDH assays showed the same effects, thus confirming the activity of the proteins. A significant increase in LDH release was seen when the cells were exposed to 
Figure 1 - Effect of $>3 \mathrm{kDa}$ fraction on MTT assay. Data are mean \pm SEM of three independent observations.

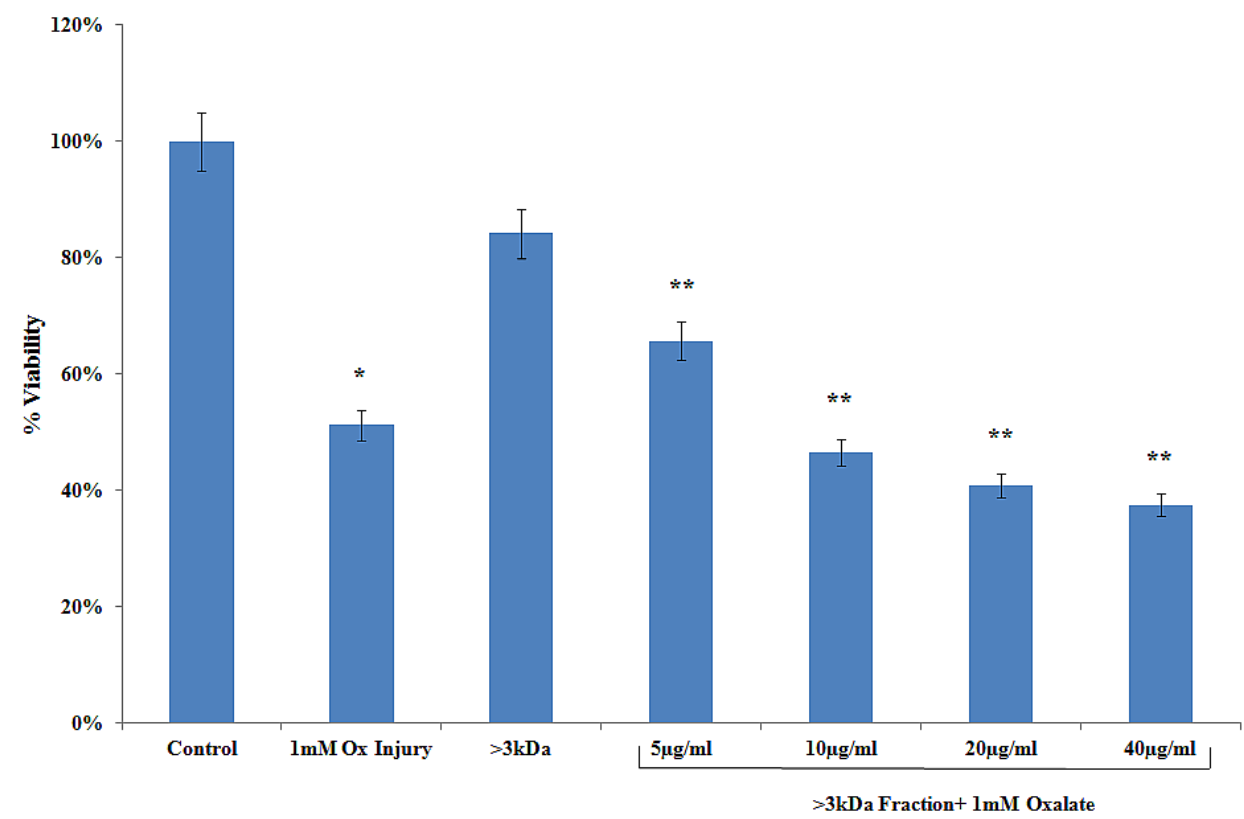

${ }^{\star} \mathrm{P}<0.01$ versus untreated control. ${ }^{*} \mathrm{P}<0.05$ versus oxalate control (the experiment was done thrice in triplicates each time).

Figure 2 - Effect of $>3 \mathrm{kDa}$ on the $\% \mathrm{LDH}$ release. Data are mean \pm SEM of three independent observations.

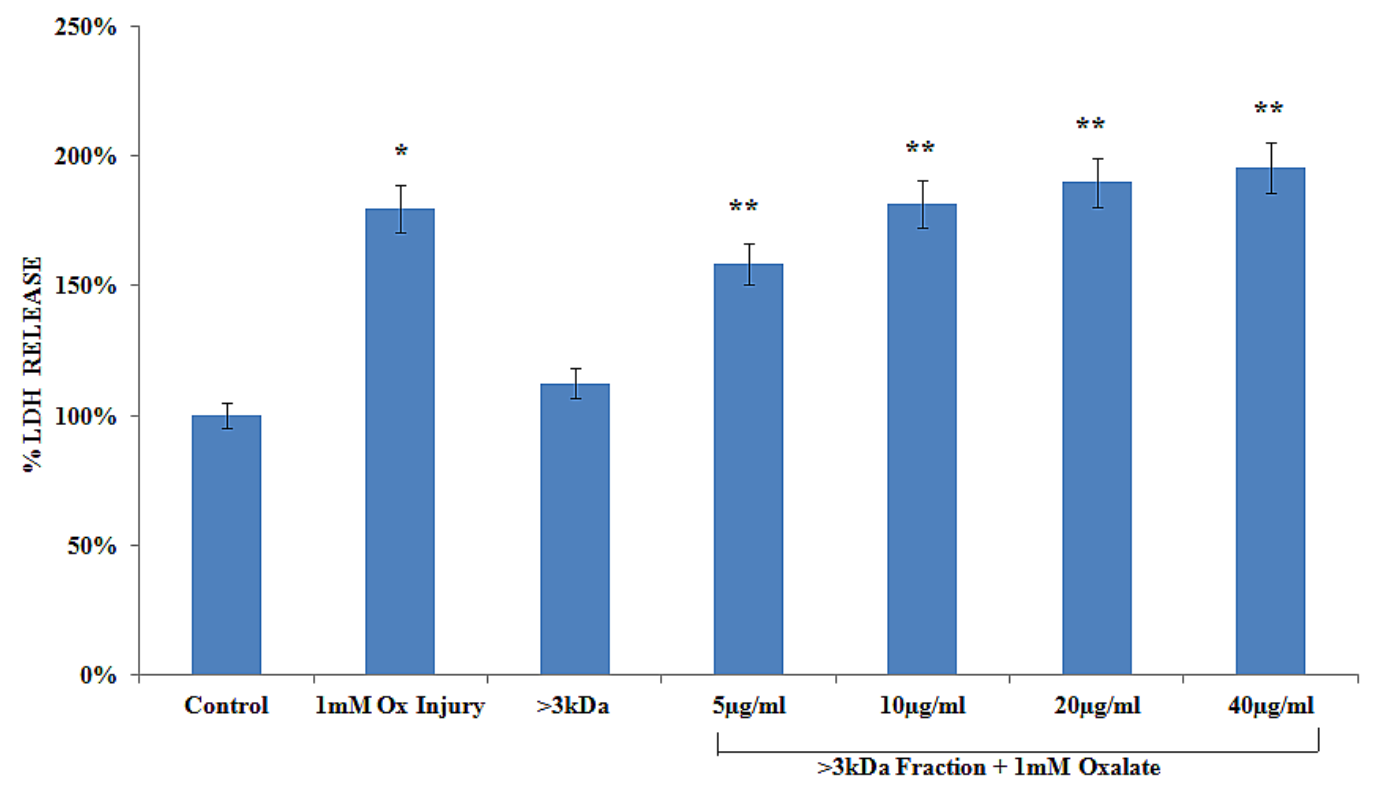

${ }^{*} p<0.05$ versus untreated control, ${ }^{* *} p<0.05$ versus oxalate control. 
oxalate alone (from 100\% of control to $179.92 \%$ of oxalate injured).

MTT assay also reflected the same pattern. $\%$ viability of cells decreased in cells from 100\% to $51.23 \%$ injured with oxalate. By these tests it can be suggested that the proteins that lead to cell injury by oxalate mask the activity of the proteins that inhibit the same.

\section{D-PAGE}

2D PAGE of $>3 \mathrm{kDa}$ proteins revealed the abundance of proteins in the matrix of human CaOx containing kidney stones (Figure-3). A total of 66 spots were detected using Biorad PD Quest Advanced 2D Analysis Software. 2D-PAGE revealed that the proteins present in the stone matrix were of both high and low molecular weight. The proteins were distributed throughtout the gel indicating the presence of both cationic and anionic proteins. Out of the 66 spots, 7 most prominent spots spread across the isoelectric points (pI) were further analysed using MALDI-TOF MS and MASCOT server. The identified proteins are given in Table-1.

\section{DISCUSSION}

The role played by the proteins present in the human $\mathrm{CaOx}$ renal stones in the course of crys- tallization is yet not clear. Some of these proteins promote crystal formation, growth, aggregation and retention, while others inhibit these processes. Their activity is often complex and depends on the urine conditions prevailing at the time of crystallization or retention. The same protein can both promote as well as inhibit a process. Under normal conditions, the crystals of calcium oxalate that form are small and well protected from crystal growth and crystal aggregation by a cover of inhibitory macromolecules. If inhibitors of crystal formation were not able to act and control their size, the final result will be nephrolithiasis $(24,25)$. Proteins which cover crystal surface and may lead to inhibition of its growth or ability to aggregate while the same proteins bound to a surface may act to accumulate salt ions and forms a template for the first nucleus. The latter will play a role when stone formation involves processes at cell surfaces and in the sub-epithelial space (26). The purpose of the present study was to explore the 2D map of human renal stone matrix proteins by MALDI-TOF-MS to throw light on the matrix proteins and also to study their effect on oxalate injured renal epithelial cells.

Proteins have a strong affınity for $\mathrm{CaOx}$ crystals (27). The role of matrix compounds is different in the formation of the stone center and in the subsequent build-up of the stone (28). The same protein which inhibits crystal formation might promote

Figure $3-2 \mathrm{D}$ page of $>3 \mathrm{kDa}$ proteins from human renal $\mathrm{CaOx}$ stones.
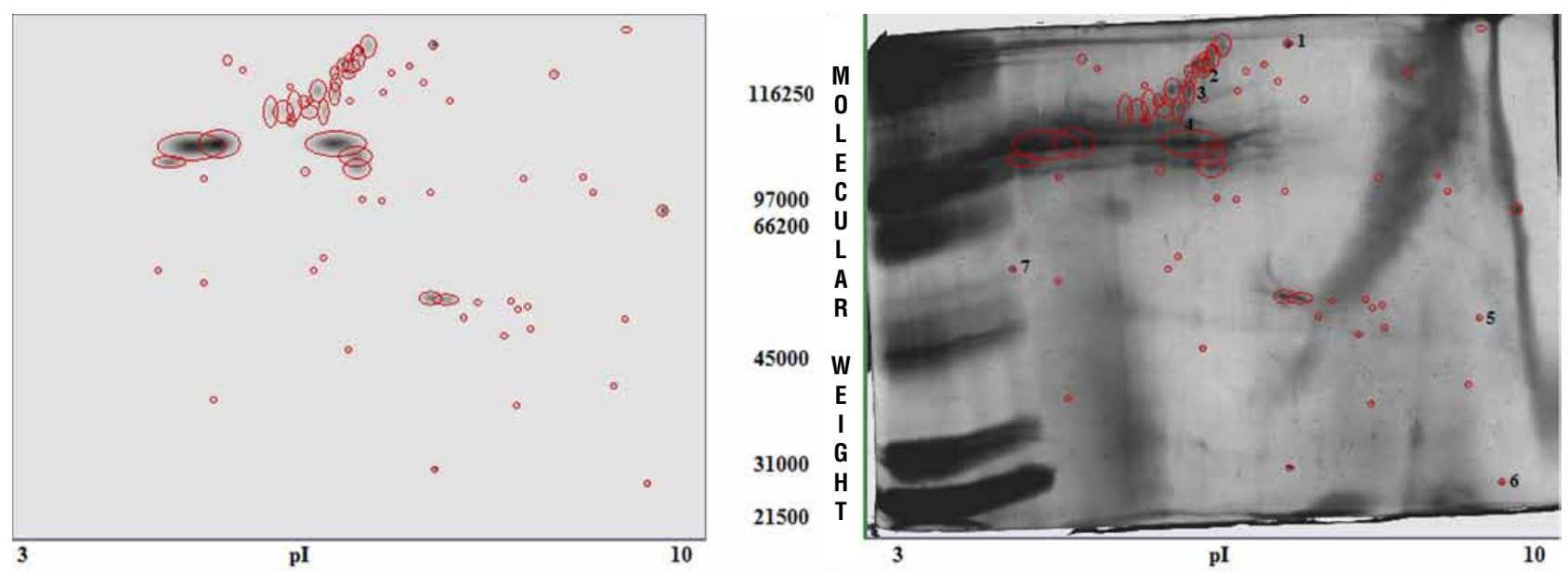


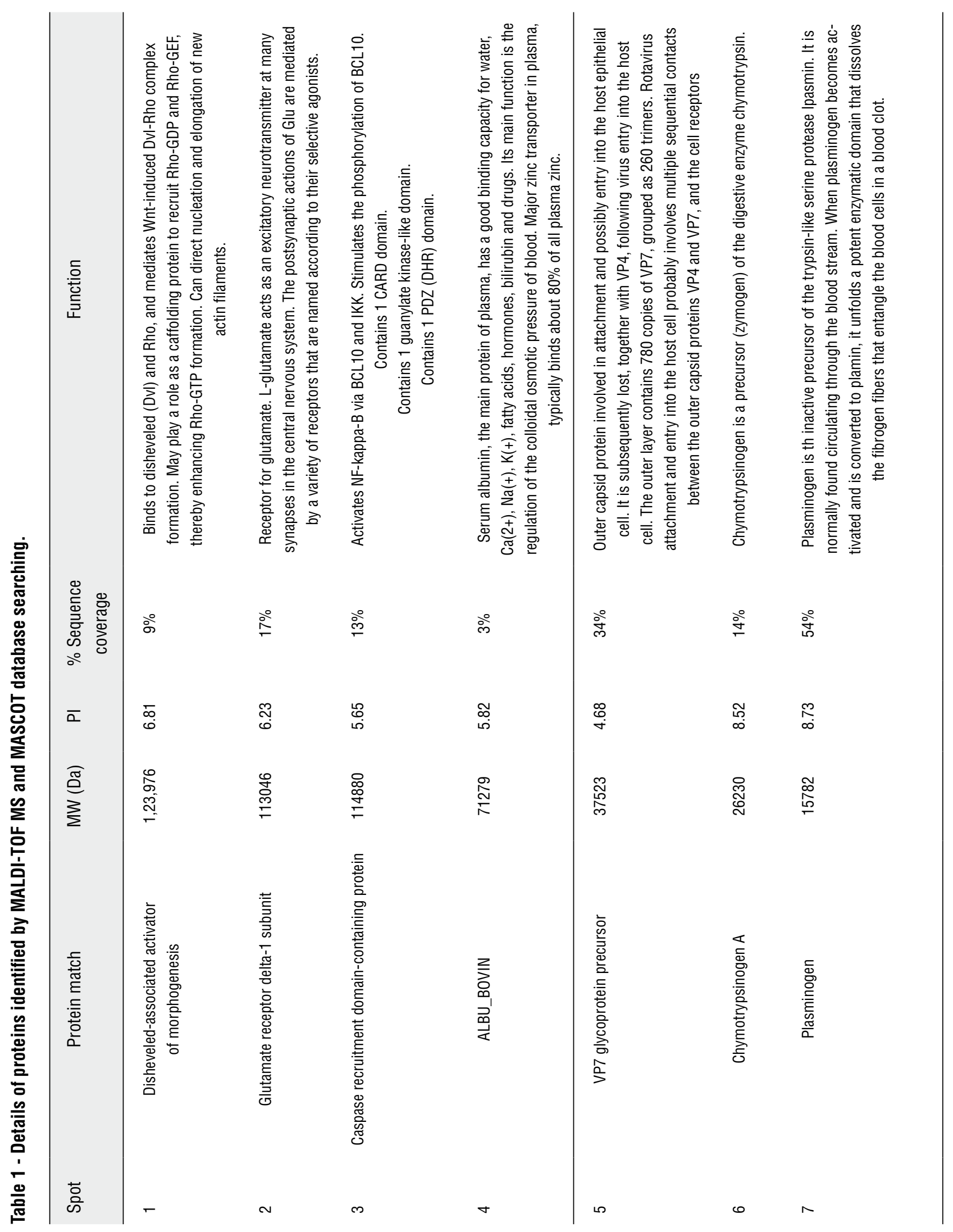


the growth of the crystal. Thus, the same protein acts differently at different stages of stone formation.

In the present study, when the $>3 \mathrm{kda}$ fraction was examined for its effect on oxalate injured MDCK cells, it majorly reflected promoter activities thereby leading to an increased cell death in a dose dependent manner. These results suggest that the proteins which are promoters of crystallization in nature mask the activity of the proteins which are inhibitory in nature, thereby leading to an enhanced cell injury, and consequently cell death. Our observations are in conformity with the observations that that renal epithelial damage can lead to increased crystal attachment (29).

The 2D map suggests that abundant proteins are present in the matrix proteins which are of both high and low molecular weight. Also both anionic and cationic proteins are present. Solution depletion (30) and examination of crystals incubated in protein solutions by transmission electron microscopy (31) tested the theory of physical adsorption of urine proteins on surfaces of $\mathrm{CaOx}$ crystals. Results showed proteins have a strong affınity for $\mathrm{CaOx}$ crystals. Adsorption of anionic proteins was sensitive to calcium ion concentration, whereas cationic protein adsorption depended upon the oxalate ion concentration with temperature and $\mathrm{pH}$ playing only a minor role.

A pathological crystallization leading to stone formation might be the net result of one or several abnormalities or defects in the control of this process. Low concentrations or structural abnormalities of crystallization modifying macromolecules or small molecules will cause increased growth and aggregation of crystals (32). Therefore, any crystallization that occurs most certainly is facilitated by promoters and it has been suggested that lipoprotein membranes from the brush border of proximal tubular cells might serve this purpose (33).

\section{CONCLUSIONS}

Studies indicate that the mixture of $>3 \mathrm{kDa}$ proteins in the matrix of human renal stones augment the renal epithelial cell injury induced by oxalate and thereby may act as promoters of calcium oxalate crystal nucleation and growth. The effect of promoters masks the inhibitors in the protein mixture thereby leading to enhanced renal cell injury. 2D map throws light on the nature of proteins present in the kidney stone matrix, however, their exact role in the mechanism of kidney stone formation warrant further investigations.

\section{ABBREVIATIONS}

CaOx: calcium oxalate

MDCK: madin darby canine kidney

DMEM: dulbecco's modified eagle's media

MTT: 3-(4, 5-dimethylthiazol-2-yl)-2, 5-diphenyltetrazolium bromide

LDH: lactate dehydrogenase

2D PAGE: 2 dimensional polyacrylamide gel electrophoresis

MALDI-TOF: Matrix-assisted laser desorption/ionization- Time of Flight

FTIR: Fourier transform infrared spectroscopy

\section{ACKNOWLEDGEMENTS}

The authors would like to thank Indian Council of Medical Research (ICMR), India and Jaypee University of Information Technology (JUIT), Solan, HP, India for providing funds to carry out this research work. We also express our gratitude to the Department of Urology, Post Graduate Institute of Medical Education and Research (PGIMER) Chandigarh, India for providing kidney stones.

\section{CONFLICT OF INTEREST}

None declared.

\section{REFERENCES}

1. López M, Hoppe B: History, epidemiology and regional diversities of urolithiasis. Pediatr Nephrol. 2010; 25: 49-59.

2. Margolis HC, Beniash E, Fowler CE: Role of macromolecular assembly of enamel matrix proteins in enamel formation. J Dent Res. 2006; 85: 775-93.

3. Wesson JA, Ward MD: Medical Mineralogy and Geochemistry: Pathological Biomineralization of Kidney Stones. Elements. 2007; 3: 415-421.

4. Parkinson GM: Crystal-macromolecule interactions in urolithiasis: lessons from healthy biomineralization systems. Curr Opin Urol. 1998; 8: 301-8. 
5. Tiselius HG: A hypothesis of calcium stone formation: an interpretation of stone research during the past decades. Urol Res. 2011; 39: 231-43.

6. Coe FL, Evan AP, Worcester EM, Lingeman JE: Three pathways for human kidney stone formation. Urol Res. 2010; 38: 147-60.

7. Ryall RL, Chauvet MC, Grover PK: Intracrystalline proteins and urolithiasis: a comparison of the protein content and ultrastructure of urinary calcium oxalate monohydrate and dihydrate crystals. BJU Int. 2005; 96: 654-63.

8. Fleisch $\mathrm{H}$ : Inhibitors and promoters of stone formation. Kidney Int. 1978; 13: 361-71.

9. Dussol B, Berland $Y$ : Urinary kidney stone inhibitors. What is the news? Urol Int. 1998; 60: 69-73.

10. Hess B, Nakagawa Y, Parks JH, Coe FL: Molecular abnormality of Tamm-Horsfall glycoprotein in calcium oxalate nephrolithiasis. Am J Physiol. 1991; 260: F569-78.

11. Asplin JR, Arsenault D, Parks JH, Coe FL, Hoyer JR: Contribution of human uropontin to inhibition of calcium oxalate crystallization. Kidney Int. 1998; 53: 194-9.

12. Pillay SN, Asplin JR, Coe FL: Evidence that calgranulin is produced by kidney cells and is an inhibitor of calcium oxalate crystallization. Am J Physiol. 1998; 275: F255-61.

13. Atmani F, Khan SR: Characterization of uronic-acid-rich inhibitor of calcium oxalate crystallization isolated from rat urine. Urol Res. 1995; 23: 95-101.

14. Stapleton AM, Ryall RL: Blood coagulation proteins and urolithiasis are linked: crystal matrix protein is the F1 activation peptide of human prothrombin. Br J Urol. 1995; 75: 712-9.

15. Aggarwal S, Tandon CD, Forouzandeh M, Singla SK, Kiran R, Jethi RK: Role of biomolecules from human renal stone matrix on COM crystal growth. Mol Cell Biochem. 2000; 210: 109-19.

16. Lowry $\mathrm{OH}$, Rosebrough NJ, Farr AL, Randall RJ: Protein measurement with the Folin phenol reagent. J Biol Chem. 1951; 193 : 265-75.

17. Hennequin C, Lalanne V, Daudon M, Lacour B, Drueke T: A new approach to studying inhibitors of calcium oxalate crystal growth. Urol Res. 1993; 21: 101-8.

18. Nakagawa Y, Abram V, Parks JH, Lau HS, Kawooya JK, Coe FL: Urine glycoprotein crystal growth inhibitors. Evidence for a molecular abnormality in calcium oxalate nephrolithiasis. J Clin Invest. 1985; 76: 1455-62.

19. Aggarwal A, Tandon S, Singla SK, Tandon C: Diminution of oxalate induced renal tubular epithelial cell injury and inhibition of calcium oxalate crystallization in vitro by aqueous extract of Tribulus terrestris. Int Braz J Urol. 2010; 36: 480-8; discussion 488, 489.

20. Moriyama MT, Miyazawa K, Noda K, Oka M, Tanaka M, Suzuki $\mathrm{K}$ : Reduction in oxalate-induced renal tubular epithelial cell injury by an extract from Quercus salicina Blume/Quercus stenophylla Makino. Urol Res. 2007; 35: 295-300.

21. Karamustafa F, Çelebi N, Değim Z, Şyilmaz Ș: Evaluation Of The Viability Of L-929 Cells In The Presence Of Alendronate And Absorption Enhancers. Fabad J Pharm Sci. 2006; 31: 1-5.
22. Lee HG, Li MH, Joung EJ, Na HK, Cha YN, Surh YJ: Nrf2Mediated heme oxygenase-1 upregulation as adaptive survival response to glucose deprivation-induced apoptosis in HepG2 cells. Antioxid Redox Signal. 2010; 13: 1639-48.

23. Priyadarshini, Singh SK, Tandon C: Mass spectrometric identification of human phosphate cytidylyltransferase 1 as a novel calcium oxalate crystal growth inhibitor purified from human renal stone matrix. Clin Chim Acta. 2009; 408: 34-8.

24. Carvalho M, Mulinari RA, Nakagawa Y: Role of Tamm-Horsfall protein and uromodulin in calcium oxalate crystallization. Braz J Med Biol Res. 2002; 35: 1165-72.

25. Kok DJ, Schell-Feith EA: Risk factors for crystallization in the nephron: the role of renal development. J Am Soc Nephrol. 1999; 10(Suppl 14): S364-70.

26. Leal JJ, Finlayson B: Adsorption of naturally occurring polymers onto calcium oxalate crystal surfaces. Invest Urol. 1977; 14: $278-83$.

27. Coe F, Parks JH: Defenses of an unstable compromise: crystallization inhibitors and the kidney's role in mineral regulation. Kidney Int. 1990; 38: 625-31.

28. Khan SR, Hackett RL: Identification of urinary stone and sediment crystals by scanning electron microscopy and $x$-ray microanalysis. J Urol. 1986; 135: 818-25.

29. Verkoelen $C F$, van der Boom BG, Houtsmuller AB, Schröder $\mathrm{FH}$, Romijn JC: Increased calcium oxalate monohydrate crystal binding to injured renal tubular epithelial cells in culture. Am J Physiol. 1998; 274: F958-65.

30. Khan SR, Maslamani SA, Atmani F, Glenton PA, Opalko FJ, Thamilselvan S, et al.: Membranes and their constituents as promoters of calcium oxalate crystal formation in human urine. Calcif Tissue Int. 2000; 66: 90-6.

31. Thamilselvan S, Khan SR: Oxalate and calcium oxalate crystals are injurious to renal epithelial cells: results of in vivo and in vitro studies. J Nephrol. 1998; 11(Suppl 1): 66-9.

32. Lieske JC, Coe FL: Urinary inhibitors and renal stone formation. In: Kidney Stones-Medical and Surgical Management (ed.), F. L. Coe, M. J. Favus, C. Y .C. Pak, J. H. Parks, and G. M. Preminger. Lippincott-Raven, Philadelphia. 1996; pp. 65-113.

33. Bigelow MW, Wiessner JH, Kleinman JG, Mandel NS: Surface exposure of phosphatidylserine increases calcium oxalate crystal attachment to IMCD cells. Am J Physiol. 1997; 272: F55-62.

Correspondence address: Dr. C. Tandon

Professor of Biotechnology and Bioinformatics Jaypee University of Information Technology, Waknaghat- 173234, Solan (HP), India Fax: + 91179 224-5362 E-mail: chanderdeep.tandon@juit.ac.in; tandonchanderdeep@yahoo.com 